\title{
THE SPECIFITY OF POETRY IN THE “KIEVLYANIN" OF MYXAJLO MAKSYMOVYCH
}

\section{Tkachenko T. I.}

\section{INTRODUCTION}

After closing in 1817 year of the Kyiv-Mohyla Academythere is not a single higher educational establishment in town. Creation of 1819 of the Kyiv Spiritual Academy, very distant from the queries of that time folk life, did not fill this blank in cultural life of city. Front-rank public of Kyiv worried about organization of university. Thus, on October, 8, 1833 a tsar signed a decree about creation in Kyiv the great university. This idea first arose up after the Polish revolt in 1830 year, when the Russian government, with the purpose of to weaken influence of Poland on Right-bank Ukraine, inculcated the policy of russification. And in 1831 Mykola I, "gendarme of Europe", set up in Kyiv the special committee in matters of western provinces, which must was offer the project of reorganization of education on Ukrainian earths with translating of all studies into the Russian language.

December 25, 1833 approved the charter and composition of the new educational institution. The official opening was scheduled for July 15, 1834 St. Vladimir's Day. October 16, M. Maksymovych became rector. So, after the Poltava, Kharkiv and Lviv, Kyiv in the thirties and forties of the nineteenth century again becomes the center of cultural life. In fact, in the early 1830s, there was an activization of publishing, caused by the foundation of St. Vladimir's University of Kyiv and the expansion of the printing base (in the mid 1830's the university operated a secret "Union of the Polish People", and in the 1840s was an institution of the related activities of the Cyril-Methodius Brotherhood).

It should be noted that the teaching at the higher education institution was conducted in Russian, Latin and French. However, Maksymovych, a natural scientist by specialty, having headed the department of Russian literature, for the first time introduces ancient Russian literature and folklore, in particular Ukrainian, into the university program. He writes a large number of works in Ukrainian, Russian and Old Russian linguistics, researches problems of common Slavic philology, is fascinated and has made considerable progress in the study of Ukrainian history, is interested in archeology and literary studies. Unfortunately, only one year the scientist rector of the university spent. He subsequently abandoned teaching (for health reasons) and devoted himself to literary and scholarly work. 
In 1820-40s Maksymovych published three collections of Ukrainian folk pearls - "Malorossyjskye pesny" (with a dictionary). The publication of songs became not only a prominent event in Slavic studies, but also contributed to the growing interest of scholars and ordinary readers in Ukrainian folk art. The prominent researcher proved the value of folklore of each people as a means of knowing reality (this idea is connected with the theory of knowledge of Yen romantics), pointing to the organic unity of folk and professional creativity.

\section{Journalistic Activity of M. Maksymovych}

Journalistic activity of M. Maksymovych began in Moscow. In 1830, with the assistance of a whole host of literary celebrities, the first issue of the "Dennitsa" almanac was published. It contained the poems of A. Delvig, the first part of "Boris Godunov" of O. Pushkin. Well-known researcher I. Kireevsky first signed here by his own name, publishing the article "Observation of Russian Literature for 1822". There were also poems by $\mathrm{N}$. Teplova " $\mathrm{K}++$ ", where representatives of the tsarist authorities saw manifestations of feelings for K. Ryleev.

Therefore, the censor - S. Glinka - was sent to the guardhouse. The almanac was supposed to be closed, but P. Vyazemsky intervened, who managed to save the publication. In 1830, Anton Delvig (nicknamed "the Gardener" in artistic circles) invited Myxajlo ("Lucifer") to take part in the publication of the newspaper, which was scheduled for 1830. But suddenly A. Delvig died. So, "Dennitsa" became the ideological heir to the Literary Newspaper. The second issue of the almanac (1831) was also successful. In 1834, the last (third) book was published, where the works of famous authors were published.

During this period, Myxajlo tried to work in a new genre for himself he wrote two fairy tales ("Merry villains", "Marco rich"), which received the praise of journalists and writers. But in the late 30's - early 40's the famous scientist found himself in the tenets of mental depression: longing for Ukraine, deterioration of health status (almost did not see left eye, rheumatic pains appeared, hemorrhage increased due to disorders of the hemorrhoid system ), collisions at the university. That is why the opening of the University in Kyiv was the impetus, the hope for a new life. In addition, Maksymovych's mother often told her son that he could find happiness (both personal and professional) not in the capital, but only in the Motherland.

Although periodicals were published in Kyiv in the 1830s ("Kyiv News”, "Kyiv Governor News”, “Kyiv Interlocutor”, "Kyiv Announcements”), these newspapers and magazines were not successful because they were government (state-ordered) appropriate content and coverage of issues. Thus, in 1839, Myxajlo began to prepare such an edition that would combine social, 
political, scientific and literary review. As the scientific and literary journal "Kyiv interlocutor" failed (prohibition of printing), Maksymovych intended to publish several separate books under the name "Kievlyanin". Well-known journalists and writers responded to the invitation to participate in the publication. They promised cooperation and wished the founder success. MyxajloMaksymovych published three books of the Kyivman almanac (1840 and 1841 - in Kyiv, 1850 - in Moscow). Despite the fact that all collections were published in Russian (through tsarist policy), they were devoted exclusively to Ukraine in their materials. It should be said about the censors of the almanac.

The last book was reviewed by "State Advisor and Cavalier Ivan Snegirev". And the first two - a prominent figure - Olexander FedotovChekhovsky, who worked with Maksymovych at St. Vladimir's University, and, although he knew about the fate of "Dennytsia", without hesitation helped his friend.

Ukrainian literature of the early nineteenth century: the inherent syncretism of styles, as writers simultaneously tested already existing and recent artistic tendencies - classicism, sentimentalism, romanticism and realism - through the prism of the national artistic worldview. But since the 1830s, romanticism, represented in four trends, has dominated national literature, namely: civic, folklore-historical, folklore, and psychologicalpersonal, according to which the types of hero (psychologically / educationallyhistorically / historically).

Romanticism - literary style, special phenomena in science and art. It opposes the dogmatic canons of classicism and logocentric Enlightenment, and combined the tendencies of Baroque, sentimentalism, Russoism and preromanticism. It emerges as a powerful artistic style at the end of the eighteenth century in Germany, England and France, and in the early nineteenth century, lately covers Italy, Poland, Austria, Ukraine, Sweden, Russia and Georgia. The basic tenets of Romanticism were elucidated in the writings of German philosophers and writers J. Gerder, together with J. Goethe, became the leader of the first all-German literary movement "Storm and Pressure", on the basis of which he formed the basic principles of German Romanticism. The author of the world-famous works "The Suffering of Young Werther" (1774) and "Faust" (1790-1833) revealed the main content of the dominant of romanticism - the idea of neglecting everything commonplace for the sake of spontaneous expression of feelings and intrinsic authenticity; all manifestations of being are polar and complementary at the same time: repulsion and attraction, separation and unity, essence and phenomenon, whole and parts, spirit and matter, man and nature. 
The importance of language as an expression of the spirituality of the national community was proved by G. Gegel. The concept of the spirit became central to his philosophical concept. The spirit (consisting of consciousness, self-consciousness, mental feeling and mind) corrects the fate of both individual and ethnic group. Therefore, the people are formed as a result of their history, receiving the image in which it deserves. An indicator of the highest degree of social development is a strong and independent state, whose formation must be made by nationally conscious and politically responsible citizens. In addition to representatives of the movement "Storm and Pressure", the contribution to the development of the aesthetic foundations of romanticism was made by the Yen romantics, in particular F. Schlegel, who contrasted "modern" romantic art with antique and classic, developed one of the central concepts of romanticism - an irony that is both ontological subjective principle and proclaimed love the essence of life. And F. Schelling noted that the aesthetic is a harmonious balance of conscious and subconscious activity, the identity of nature and freedom, sensual and moral foundations. He owns the concept of "intellectual intuition", which became the main means of knowledge of reality for artists of the early nineteenth century. Analyzing the above-mentioned considerations of philosophers, one cannot but notice their connection with the basic theses of the "cordocentric" theory ("philosophy of the heart") by G. Skovoroda, who defined the heart as the center of faith, spirit and mind. After all, the romantics saw the world through the prism of their own inner self, rejecting conformism and following the well-known concept of a wandering teacher- "labor", emphasizing the uniqueness and self-worth of each person.

Finally, in the Romantic era, it was recognized as natural and understandable thing by everybody: equality of people means equality of cultures and equality of ethnic groups. By the way, it was the romantics who finally approved the syllabic-tonic system of verse, although they resorted to other versification systems depending on the creative plan (stylization of folk song or glorification of the past). In terms of genre features, lyric-epic (ballad, poem), lyric and dramatic works were striking with thematic diversity. Thus, as to artistic style, to romanticism such signs are peculiar: non-acceptance of ordinariness, presentation of "life of spirit", cult of feelings, actualization of folklore, penetration and deepening in the inner world of man, a perceptible reception or "poetic intuition", lyric filling and sounding emotionality; opening of God by rational not cognition, but in tradition and feelings; reasons of tragic fate of personality (consciousness is through external and inner world), "world melancholy", "space pessimism"; requirements to the artist are "principle of individuality" (free "I"), freedom, abandonment from binding overs and "free form and work", fantasy, originality, originality; show to nation as integral 
unity and confession of art by the greatest value that is the display of deep essence of our life.

In Ukraine romanticism is also presented by a few cells that had at the same time excellent looks to the activity and priorities. Kharkiv School of romantics operated at the Kharkiv University in 1820-30s under the direction of IzmayilSreznevskyj. The figure of prominent scientist united two groups the representatives of that were O. Shpygoczkyj, L. Borovykovskyj, Fedir and OrestYeveczki, I. Roskovshenko, A. Metlynskyj, M. Kostomarov. Infatuation for the ideas of J. Gerderand F. Schelling the Kharkiv romantics chose for an aim - to accent historical memory, form historiosophical conception of the Kozaks and investigate the "mysterious soul" of people - mentality, concentrated foremost in the folklore's standards (story, fairy tales, duma, legend, historical songs) ${ }^{1}$.

At the same time, they ignored pressing social problems, avoided acute political reprimands, as they saw in the rehabilitation of past revival of interest in Ukrainian in the world. Instead, representatives of the "Ruska Trijcya”(first of all, MarkianShashkevych), a Western Ukrainian unit of Romanticism, raised the pressing questions of free development of language and literature, its use in the educational and scientific fields, unification of primordial Ukrainian lands and the achievement of least Ukrainian autonomy, and above all, "to resurrect the nation for spiritual and community life".

The activity of the Kyiv School of Romantics (1840s), which is presented by the works of M. Kostomarov (dramaturgy), M. Maksymovych, and P. Kulish, is related to the requirements of the Galychans. In contrast to the exceptional idealization of the past by the "Kharkiv", the present and future main motive behind the artistic texts of the Kyiv Romantics was the present and the future.

The legacy of the world-renowned artist Taras Shevchenko is also attached to the Kyiv School. Although romanticism is inherent only in the early period of the poet's work, he fully revealed the genius of the Ukrainian author. In his works T. Shevchenko rejected the typing of characters, showing a psychological portrait of the hero (the poem "Kateryna", the ballad "Prychynna"). He emphasized the main problem of a non-state country, emphasizing ethno-consolidation, which lies not in the passive contemplation and pardon of the past, but in the hard work of today. The appearance of Kobzar in 1840 testified to the statement of "full" Ukrainian literature, interesting and comprehensible for all sections - in the spirit of the people, but for an educated society.

The origin of Ukrainian romantic literature and ideology took place in Kharkiv at the turn of the 1820-30s, where it has almost died out for decades.

\footnotetext{
${ }^{1}$ Бовсунівська Т. Феномен українського романтизму. Київ: Академія, 1997. Ст. 27.
} 
Instead, in the late 1830s, Galychynabecame more active, and as early as the 1840s, the first place belonged to Kyiv, namely the Cyril-Methodius Brotherhood. Due to administrative persecution, the centers of Romanticism were destroyed because the imperial power could not allow the revival of the lost ethnic consciousness of the once mighty Ruthenians. The latest embodiments of the basic principles of style were the collections of songs by A. Metlynskyj (1854), J. Golovatskyj (1863-65), the proverbs and sayings of M. Nomys (1864), "Notes on Southern Rus" (1856-57), and the journal P. Kulish "Osnovy" (St. Petersburg, 1861-62). At the same time, romanticism found continuation in the creative work of the artists of the second half of the nineteenth century. For the reign of realism, it acquired new visual and expressive shades in the twentieth century. - heritage of "neo-romantics", generation of "rozstrilyane vidrodzhennya", representatives of "Prazka Shkola" and Shistdesyatnyky. The Romantics rehabilitated folklore, defining the central notion of literature as the "spirit of the ancestors", combining history, poetry and ethnography ${ }^{2}$.

Therefore, in the artistic writing of the early nineteenth century. used a lot of folk-poetic images-characters, issues, topics and subjects in national mythology. Thanks to the popularization of the acquisitions of generations, the "fashion for Ukrainian" began, as evidenced by the artistic interpretations of the conflicts of Ukrainian history by Slavic and Western European writers, especially during periods of national liberation competitions.

At the same time Ukrainian romantics became interested in translations of world texts. In this kind of artistic interchange, realized in the early nineteenth century, the writers proved the equivalence and originality of the national fiction, and established a connection between Ukrainian literature and the world literature.

Naming the main features of the national variety of this style, it is advisable to compare the romantic works contained in M. Maksymovych's almanac with the contemporary works of Ukrainian romantic poets. The ratio of works of prose and poetry in almanac books is different. If the prose is available only in the first and second books, then the lyrics are stated in a considerable amount in all editions of Kyiv. Of course, the level of poetry is unequal. But, in response to the criticism of researchers about the skill of authors of poetry in the anthology, it can be noted that all poets of the anthology are popular, wellknown, talented figures of their time, whose life and creativity are certainly interesting, multicolored and worthy attention of future generations, recognizing the fact that most are more social and cultural figures than artists.

\footnotetext{
${ }^{2}$ Кіевлянин. Книга перша. Київ: Університетська типографія, 1840. Ст. 2.
} 
However, the compiler did not dare to publish a single poem on acute political topics. In addition, from the large number of authors and poems that were to be published in the almanac (sent their works by Y. Golovatsky, I. Vagilevich, A. Mogylnytskyj, invited to T. Shevchenko's cooperation), MyxajloMaksymovych selected the most neutral and "trustworthy" ones.

In total, 39 poetic works by 18 authors were published in the anthology (19 - in the first book, 2 - in the second, 18 - in the third). In the poetry selection we see some innovations, such as: new genres in Romanticism (for example, landscape poetry and free poem by E. Grebinka- "The Girl for the Piano”), participation of romantic poets (N. Teplova, E. Rostopchina), the embodiment of the fate of a female artist ("Three Souls" by K. Pavlova).

The poems that open the editions have the same name - "Kiev". We can say that this is the "official" poetic page of "Kiev". The author of the first work is O. Khomyakov - one of the main ideologues of Slavophilism in Moscow. That is why the poem becomes political. People from all corners of the Russian Land are heading to Kyiv as a shrine. In this way, the unification of Russia and Ukraine is approved, but Poland is despised for "brazenly selected" in Russia by Western Ukraine.

Instead, V. Benedict's poem "Kiev" is an ode to an ancient and beautiful city. The holiness of Kyiv and the beauty of Ukrainian nature are sung. It should be noted that both works were written at the request of Myxajlo Maksymovych specifically before the appearance of the almanac.

After the poetry that opened the publication, it is advisable to consider the own lyrical part of "Kievlyanin", the most famous writer of which was the Russian romantic V. Zhukovsky. In the anthology there is only one of his poems, called "The Flowers of the Covenant". Probably, in order to facilitate the censors, the publisher extracted from the art treasury of the poet exactly the work ("Flowers of the Covenant"), which was written in 1819 specifically at the request of Princess Alexandra. But it was Zhukovskywho first discovered the beauty of the spiritual life and poetically reflected it. The lyrical hero tries to express what is not transmitted in words - his individual feelings: the trembling waiting for the unspeakably beautiful and mysterious minutes, the pleasant memories of them and the hope to feel those moments again make up the content of this work. Sometimes we are able to see the glimmer of eternal and heavenly beauty, approaching the ideal. Sometimes we find this insight in the humblest of things.

Smoothness, musicality, sophistication, individual marking of the mental world, attraction to an indefinite ideal, feelings that can only be approximated in words - this is what gave Zhukovsky romanticism. These traits have become one of the defining poets of this style. 
The only representative of Ukrainian poetry in the almanac was E. Grebinka, albeit with a Russian-speaking poem. Music is metamova, understood equally by everyone, but at the same time everyone perceives it differently. Subjective feelings and feelings of the lyrical "I", which is identical to the author's, are covered in the work of art. Considering the two poems that most clearly depict the specificity of romanticism, in particular, represent the style of artists in this area, it is necessary to determine the theme of poetry and the image of the lyric hero in romantic works.

The glorification of the past, its own appeal to battles and military victories - is an indispensable component of romanticism. Writers exaggerate patriotism, heroism, a decent acceptance of death for their homeland everything was once in the past, but one must strive for contemporaries. The chanting of a story is sometimes concentrated in a certain character that holds glory forever.

There are several such characters in Ukrainian poetry, and the first among them is a song that reflects the history and spirit of generations.

For Ukrainian romantics, the past of the Motherland is an ideal. Particularly striking combination of freedom of the country, loyalty to duty and democracy appeared in the times of ZaporizkaSich. This is a period when the Kozaks and Zaporozhci themselves elected the chieftain and getman, guided by the eternal law and national morals, fought for universal interests, for their people. Therefore, the great history of the artist was seen in the symbolic images - things that helped to gain the will of their land, which are preserved in each family as immortal monuments of past times of glorious struggle. Not to bring back the past, but you can take it as a model to fight desperately for the better fate of your country.

Although they (things-symbols) are always crying out for free Ukraine once, trying to arouse the action, rebuking the offspring for passivity, fear, mental inferiority. If for Russian writers the hero is an abstract ideal figure, then Ukrainian artists see the embodiment of physical and moral perfection precisely in the Kozaks, often pointing to famous historical figures (S. Paliy, I. Mazepa, B. Chmelnytsky, P. Sagaidachnyj, I. Pidkova, P. Polubotok, S. Nalivayko).

\section{Ukrainian History in Romanticism}

Romantics are also reminiscent of magicians - Kozak-Xaracternyk who, according to folk tales, could treat, divine and overcome the enemy only by sight. It should be emphasized that the theme of the historical past, the era of KyivRus and the Kozak's period, is dominant in Ukrainian romanticism. At the same time, a grave is an incorruptible monument to the glory and grandeur of ancestors and a silent constant reproach to unworthy descendants. Therefore, poetry of historical topics contains many reminiscences, allusions, folklore 
stylings. But comparing the present with the past always shows the superiority of the latter in the evaluative position of the contemporary. Ukrainian romantic poetry is characterized by an inactive historical lyric-epic - singing the glorious struggle of the Kozaks for the freedom of their country as the best of fate and expressing their disdain for unworthy descendants. Modernity for the Ukrainian is a hopelessness, as there is no hope for the liberation of Ukraine, because there are no more Kozaks who would be able to fight. Thus, the national past acts as the substantive dominant of the Ukrainian artists creativity and prevails over Russian romanticism ${ }^{3}$.

It should be emphasized that even nature is concerned with the sufferings of its earth, just like man. She is an eternal witness of sorrow and joy, torture and mercy, defeat and victory of Ukraine. An appeal to the Dnipro - the water element is not accidental, because it is water that can both destroy and give impetus to a new life. A new generation of nationally conscious Ukrainians must, first and foremost, revive the ancestral heritage preserved in the genetic memory of generations, in order for modern life to be the pledge of a happy future for a renewed independent ethnos.

The reinterpretation of cosmogonic images is often the semantic core of the poetry of romantics. Wind becomes a polysemantic symbol. It embodies a harmonious combination of freedom and power, constantly spreading between heaven and earth. The liberty is his fortune, which he does not betray, for he can do as he pleases. The lyrical hero is jealous of the wind: therefore indifferent to the unjust social system, the cruelty of people. He knows neither the impossibility of the desired nor the imprisonment of freedom, for the wind is its absolute embodiment.

Wind is the center of the souls of the ancestors, through which the ancestors pass on the knowledge of the past to the generations to come, reviving young people's courageous actions.

Ukrainian Romanticism has established a clear opposition to the pastpresent - the freedom-bondage. This is due to both the historical events and the current situation (political, cultural) of Ukraine, which provoked the artists to appeal to a sense of national dignity. It was clearly seen in the Kozaks. Mention of the glorious history of the native land is inevitably linked with the love of the Motherland, the longing for which the Russian and Ukrainian romantics unite in long journeys, which may end in a permanent place of residence.

But for a Ukrainian, a foreign country is first and foremost associated with detachment from the family (both in the narrow sense - parents, wife, bride, children, and in a broader sense - people, motherland, culture, mentality). Therefore, the break with the Motherland is the most grief where loneliness and

\footnotetext{
${ }^{3}$ Кіевлянин. Книга друга. Київ: Університетська типографія, 1841. Ст. 147.
} 
orphanage are combined. This topic is painful for the Ukrainian nation. At first, it embodied the feelings of a Kozakk who was leaving to defend his land. However, later on, these topics changed their focus from heroic-historical to socially-tragic: the wanderings of the storm, the cruel fate of the mercenary, the recruiting and the political exile.

Humility before the verdict of Fatum- to exist in a foreign land - leaves the lyrical hero with only one purpose of life: the desire to rest on his earth, in his family circle, becomes a cherished desire. The inability to bridge the gulf between dreams and reality leads to a bifurcation of "I", which seeks to find harmony in the world order that is unlikely to succeed in earthly life. Therefore, romanticism is always a protest against what exists. While revealing the conflict between personality and society, romance emphasizes several aspects. First of all - a social system where the material prevails over the spiritual. Romantics condemn a pragmatic and self-righteous inhabitant, a man with a dead soul, where the meaning of life is profit, material enrichment, and hence spiritual poverty. Romantics become spiritual opponents of philanthropy, disparaging the unjust social system. That is, first of all, the social problems that have become widespread are revealed.

That is why in Ukrainian poetry the fate of the cover is often covered, the theme of the underprivileged - orphanage and aging is revealed. It is worth noting that Ukrainian artists use the technique of artistic parallelism, comparing the human and natural worlds, where there is also a division into those who have power, rich and poor, whose tears and lives are worthless. In addition to the antinomic couple "spiritual - material", the romantics contrast the personality of the crowd, the capture of which another talent or power is fleeting and not trustworthy: choosing a certain idol, the crowd immediately seizes on others, destroying the previous - so it will continue. Being free from the approval of the crowd, from social troubles, and even from the present reality, which is possible only through internal emigration or escapism, is the main pledge of happiness. Hence the desire for a harmonious restructuring, of another world, where freedom of spirit is possible, life is by calling, by the falters of the heart.

At the same time, Ukrainian artists do not sharply contrast the crowd and the individual. In fact, they treat this topic in their own way: they always emphasize that talented people give talented people. A true artist will always find the response of at least one listener who will appreciate his work by heart and recognize his thoughts and feelings in a work of art. Romantics have outlined several worlds - the haunts of an exhausted sophisticated soul. One is nature, because it is dominated by the kind of harmony so lacking in happiness.

The spiritual experiences of a person alienated from the world of social relations reveal all the richness and diversity of the content of the outside world, 
contemplating nature, finding a refined image in emotionally conscious details of the landscape. Nature itself reveals multicolours of its colors only when it becomes the subject of emotional experience, sensory perception, reflection of the lyrical hero, as if the projection of his spiritual world. Purely landscape lyrics expresses the admiration and admiration of nature. After all, its external, visible image, harmony and natural movements are manifestations of its soul. Romantics are in love with nature - the beauty and grandeur of the free element ${ }^{4}$.

If in philosophical reflections the lyrical hero contrasts the eternal nature with the corruptible and transient human life. So in the psychological perspective, the state of the lyrical "I" and nature are identified. Unlike human society, nature is characterized by humanity and kindness to all who need its help. Therefore, nature is often the savior-source of life. So nature is a harmonious element. Romanticists have created their own view of it: the landscape has lost its objective essence and has become a poetic image of the soul's hero.

In addition to the earth's harmonious natural structure, another perfect world appears in the sky - "there is no night in the sky" - an incredible combination of purity, beauty and grandeur. Heaven also attracts the attention of romantics because it acts as the abode of God. The lyrical hero often seeks the help of the Lord, since only He can give moral strength and save from the spiritual degradation that grows daily between people and within man. Christ is the savior of a person who always hears and understands. Only He preserves the love of His unworthy children - people, helping them to be themselves, overcome the darkness of real life and even overcome death. Only God gives the power of the spirit that relies on faith - the one and the certain, the true and the reliable. Before the Lord, all levels - He rewards people for their life on earth, their spiritual qualities

The theme of the just judgment of the Lord is quite common in the works of Ukrainian romantics. Man is so sinful that he can pollute even his angel with his filth.

The depth of disappointment in reality, even more so than heaven, leads to despair. Reflections on the special, high, divine nature of man, distorted by his real being and lost on the earthly path - are inherent in romantic consciousness. The heavenly system, the world-absolute, the perfect harmony unattainable for the lyrical hero, who will still seek to reach these heights both on earth and in heaven.

After nature and the sky the third refuge of the lyrical "I" romance determine the far beautiful terrain. It is worth noting that in Ukrainian romanticism this theme was not clearly revealed. Since happiness is only

\footnotetext{
${ }^{4}$ Турчин В. Эпоха романтизма в России. Москва: Искусство, 1981. Ст. 468.
} 
possible for a Ukrainian in Ukraine, paradise on earth is only a ghost. In the works dedicated to this topic (search and escape), the utopian paradise of earthly reality is clearly opposed - the human shameful device that selects the best (above all, the internal spiritual equilibrium) and where the romantic is forced not to live but to exist. The romantic is committed to a dream that reigns only at night. After all, the romantic hero has to obey the rules of the outside world. So determined by fate - an evil final that seems to mock the romance over which the burden of reality hangs.

The pain of vain hopes is heightened by the loneliness of the lyrical hero.

The theme of lost youth is common to Russian and Ukrainian romanticism. After all, in his youth, man has enough physical and moral strength to compete with the cruelty of the realities of being. Although reality does not give the slightest chance of confronting it. However, youth has no experience. She is able to make mistakes without going into error, because she has a lifetime ahead. This is a time when you can live in dreams and truly believe in the embodiment, the fulfillment of all your hopes, breaking to the ground for their realization. A full-fledged life in the social hierarchical world is impossible, and a miserable existence is terrible. The person is lonely and is a closed personality, which cannot overcome the fatum.

The person was disappointed in the possibility of a just restructuring of the world and unable to destroy the social system. Therefore, the lyrical hero is aware of his doom for suffering through futile hopes and pursuits of an unknown perfect world - an eternal walk that will end with nothing. However, there are moments for which the romantic lives - these are the moments when dreams and reality come together, and the soul believes that it really is. The lyrical "I" undergoes a fleeting but wonderful moment of happiness. It should be noted that to express the most subtle nuances of the soul, Ukrainian romantic artists often use imaginative folk symbols, in particular bird. I. Ogienko (MetropolitIlarion) in the book "Pre-Christian Beliefs of the Ukrainian People" tells the folk legend of the cuckoo's family, where this bird represents orphanage and widowhood. Raven also always acts as a harbinger of evil, a symbol of cunning. Instead, the swallow embodies the highest degree of goodness and love, the warmth of spring and hope. Not surprisingly, in Christian symbolism, this bird is portrayed as a person who prays to God for prayer and intercession. That is why swallow in folk and literary works is identified with mother. It is worth noting that in Ukrainian romantic poetry there is an avian image that symbolizes the artist himself - the nightingale ${ }^{5}$.

However, the image of the word artist has several hypostases in the poetic world of romantics.

\footnotetext{
${ }^{5}$ Кіевлянин. Книга третя. Київ: Університетська типографія, 1850. Ст. 135.
} 
It is advisable to emphasize the symbolism of the boat inherent in Ukrainian and Russian romanticism, which has different semantics. In the poetry of Russian artists, the lyric "I" envies the boat.Instead, Ukrainian poets identify an estranged person (a romantic) and a boat that is devastated by the elements. The boat is a symbol of romance, its external and internal life, a sensual personality that no one understands.If in Russian romanticism we have the opposition "boat"- the lyrical "I", then Ukrainian artists draw a parallel between the boat and the romantic hero.

Romantics paid particular attention to the creative personality. They regarded art as the highest form of human activity, and the artist as a sage and prophet who, through the power of his genius, imbues the secret depths of life beyond the reach of ordinary people. Ukrainian artists have found the image-symbol of the embodiment of freedom on earth, since this person can live according to his own needs and desires - he is independent of the dangers of others.

In Ukrainian literature, a model, the ideal artist was a kobzar, a bandurist- a figure who permeates the heart of the people with the spirit of glorious antiquity. Not without reason in the Ukrainian history appeared the famous Kozaks / Gaydamak-musicians, who inspired the brothers to fight as they went along with the army to the enemy. Subsequently, kobzars, bandurists, and lyricists became interconnected, telling the story of the national liberation struggle of the Ukrainians.

Music can communicate with God. At the same time, it coexists with the natural elements that help it preserve the memory of different generations.

It is appropriate to note the decisive role of the song for the artist. It is a symbol of the people's soul and the most precious treasure to be inherited. The connoisseur of the song, her performer - the carrier of the spirituality of the nation. Kobzar preserves and protects the culture, traditions, history of its people and homeland. Bandurist, kobzar, lyricist is the best and most respected artist of all time.

First of all, a person of art must be strong in spirit, live in faith and love, seek the ideal - the realization of dreams and hopes, even if unfulfilled. Her or his fate is the hardest and most beautiful at the same time.

According to the romantics, only in the art are the creative, aesthetic and emotional, human abilities fully revealed. Art requires constant work of the soul and heart, self-improvement and development of creative gift - only in such conditions a full life is possible. Therefore, the romantics preached the absolute freedom of the artist - a genius, independent of power and the "nearby" crowd.

Instead, the Ukrainian artist does not separate himself from the people for whom he works.First of all, the poet is the son of his country and the expression of the hopes of ordinary people. It accumulates in the works of 
emotions, feelings, feelings, memories and dreams of Ukrainians. The artist addresses his work to everyone, regardless of status, age, gender ${ }^{6}$.

Romantics created their own world. They rebelled against the cruel, antihuman social system concerned with everyday problems; drew attention to the inner nature of man, putting forward a priority - the self-worth of the individual. In this way, the romantics continued the tradition dating back to the Renaissance and especially manifested in the art of sentimentalism.

Perceiving individuality as the antithesis of society, the romantics formed antinomic couples that defined the subject of their works, namely: the world of material relations - the beauty of spiritual life, nature as a living organism - civilization as a mechanical, artificially created system, freedom from birth - social bonds. For a romantic artist, the idea or feeling of his work is concentrated at a certain point, and the rest of the space is just the background. The main thing in the romantic work - the hero. Man for romance - a small universe, a microcosm. Hence, the immersion in the mystery of the human soul, the attraction to the unconscious, intuitive; a description of the whole spectrum of feelings, emotions, feelings, in order to reveal a unique, individual in a person.

Romantic hero - lonely and despondent because of futile attempts to change society or overcome an evil fate, a sufferer. He lives in two worlds: real and his own, artistic. The eternal search for the ideal of the romantic sees in the knowledge of the heavenly structure of God, in the beauty and grandeur of nature, in the far unknown land of his dreams. In an effort to follow the cult of individuality, romance, though they were the forerunner of modernism, still endowed their characters with common features. Therefore, the characteristic feature of romanticism is subjective-lyrical typing. The romantic character alien to the environment turns out to be in agreement with the author, and in some places he acts as his double.

That is why the romantic lyrics present the artist's emotional identification with the personality and destiny of his hero. It is worth noting that the romantics challenged society, emphasizing freedom - social, personal, creative, protecting the person and the artist, who have the right to live and create according to their own rules, which can contradict the rigid standards, breaking the established limits. Therefore, the basic foundation of the aesthetic code of Romanticism is the affirmation of freedom as the highest value of life. These are universal traits inherent in romanticism in general. But it is appropriate to single out the features of Ukrainian romanticism itself, since the almanac was published in Ukraine and for Ukrainians.

\footnotetext{
${ }^{6}$ Українські поети-романтики: поет. твори / упоряд. і прим. М. Л. Гончарука. Київ: Наукова думка, 1987. Ст. 256.
} 


\section{CONCLUSIONS}

So, considering the romantic lyrical world of "Kievlyanyn" and comparing it with the works of Ukrainian artists gives grounds to conclude.

The poetry of the publication was organically combined with the general figurative-thematic focus of Ukrainian romanticism. However, a significant drawback must be noted. Unfortunately, fearing to include poetry of Ukrainian authors in the almanac, M. Maksymovych lost the national color of Romanticism. Ukrainian artists have highlighted the problems caused by Ukraine's political situation. It is impossible to imagine this style in Ukraine without glorifying the historical past with folklore intertext, illuminating the subjective disturbances of the soul. It was Romanticism that marked the transition from impersonal to personality and psychological motives, which would be decisive for the latest Ukrainian literature.

Almanac "Kievlyanin" - the first non-governmental Kyiv edition. However, the format of the books testified to the supremacy of the authorities over the compiler's desire to make a genuine exclusively Ukrainian publication - no Ukrainian-language work, except folklore intertexts in the artistic prose of G. Kvitka-Osnovyanenko and P. Kulish. Myxajlo did not dare to publish poetry of Ukrainian artists, except for the Russian-speaking poem by E. Grebinka and excerpts of poetry analyzed by the publisher and printed by Maksymovych. Moreover, he missed a landmark - the Lviv Chronicle, sent by Y. Golovatskyj. All the poems that make up the lyrical selection of the almanac are "trustworthy", neutral in content, mostly dim in appearance, and unpretentious in form. Even in the scientific and journalistic part, moderate thoughts predominate (in stories-studies on Ukrainian history, culture is almost always a noticeable bias towards Moscow). At the same time, we can note the remarkable design of the almanac and the thoughtfulness of its structure, which could be modeled on modern publishers. The best book is the second book, containing poetry and fiction, as well as various articles (historical, philological, local lore), whose authors must appeal to the recipient. The work of the researchers, published in the publication, is striking the argument, which is achieved by the vast amount of material used and the ability to notice and distinguish the most essential - an example of scientists of all time. It is in the almanac that the first writing attempts of P. Kulish were placed. In addition, Myxajlo Maksymovych, through his publication, took part in a discussion on Ukrainian spelling.

Pointing out the shortcomings of "Kievlyanin", it should be borne in mind that the editor had to constantly withstand numerous censorship oppressions, removing a certain amount of material ready for printing. He had to explain to the authorities, testing the nerves and health for strength. After all, the scientist did not forgive neither Koliyivshchyna nor the opinions, albeit 
fugitive and veiled, about unification of Ukrainian lands - the only language presupposes the existence of a single country. In addition, Maksymovych wanted to do a few more issues of the almanac, as evidenced by the words at the end of the articles "The Book Old Stories of Yuzhnoruskaya" and "Pereyaslavsky Tales" - "Continued to come". However, Myxajlo was unable to realize, to realize his intentions, due to lack of physical and moral forces. Maksymovych's almanac "Kievlyanyn" as the first non-governmental Kyiv publication on Ukraine and for Ukraine, played a significant role in the development of national culture. Not only contemporaries but also descendants, he deserved attention.

\section{SUMMARY}

The article deals with the specificity of poetry in the "Kievlyanin" of Myxajlo Maksymovych. It investigates the main formal and sense components of the poems and picks out the peculiarities of the writer's individual style. The research reveals the author's accents in the reflection of vital problems.

The writers raise philosophic, political, national, educational and ethical questions, describe the different emotions of the characters, present the variety of the genres, interesting characters and different functions of the narrator.

So national romantic style has the following features: 1) the dominant character of folklore origins - the folklore-renaissance component, we see organic unity, interconnectedness, folk and professional creativity; 2) the significance of history, the glorious past, conditioned by the status of Ukraine at that time: the Kozaks are opposed by unworthy descendants who are only able to endure suffering; 3 ) national superiority over universal - ethnomarking: we meet the promotion of ethnic culture, recognize the nuances of the Ukrainian soul, the traits of national mentality, show and expose the most pressing problems and issues that are of concern to society.

\section{REFERENCES}

1. Бовсунівська T. Феномен українського романтизму. Київ: Академія, 1997. 154 с. 1840. $254 \mathrm{c}$.

2. Кіевлянин. Книга перша. Київ: Університетська типографія,

3. Кіевлянин. Книга друга. Київ: Університетська типографія, 1841. $328 \mathrm{c}$.

4. Кіевлянин. Книга третя. Київ: Університетська типографія, $1850.218 \mathrm{c}$.

5. Турчин В. Эпоха романтизма в России. Москва: Искусство, $1981.550 \mathrm{c}$. 
6. Українські поети-романтики: поет. твори / упоряд. i прим. М. Л. Гончарука. Київ: Наукова думка, 1987. 588 с.

\section{Information about the author:}

Tkachenko T. I.,

Doctor of Philology, Associate Professor at the Department of Slovenian Philology and Journalism, Academic and Scientific Institute of Philology and Journalism,

V. I. Vernadsky Taurida National University 33, John McCain str., Kyiv, 01042, Ukraine 